\title{
STUDY OF C.I. ACID ORANGE 7 REMOVAL IN CONTAMINATED WATER BY PHOTO OXIDATION PROCESSES
}

\author{
N. DANESHVAR * \\ S. ABER \\ F. HOSSEINZADEH
}

Received: 01/08/06

Accepted: 27/09/06

\author{
Water and Wastewater Treatment Research Lab. \\ Department of Applied Chemistry \\ Faculty of Chemistry (Excellence Center of New Materials \\ and Clean Chemistry) University of Tabriz
}

Tabriz, 51666-16471, Iran

*to whom all correspondence should be addressed:

Fax: +98 4113340191

e-mail: nezam_daneshvar@yahoo.com

\begin{abstract}
C.I. Acid Orange 7 (AO7) commonly used as a textile dye and could be degraded by UV/ZnO, $\mathrm{UV} / \mathrm{H}_{2} \mathrm{O}_{2}$ and $\mathrm{UV} / \mathrm{H}_{2} \mathrm{O}_{2} / \mathrm{Fe}$ (III) (photofenton) processes. In the photocatalytic degradation of dye by UVIZnO process, effect of some parameters such as UV irradiation time, presence of $\mathrm{ZnO}$ and $\mathrm{UV}$ irradiation, $\mathrm{pH}$, concentrations of $\mathrm{ZnO}$, dye, $\mathrm{H}_{2} \mathrm{O}_{2}$ and ethanol was examined and first order reaction rate constant was calculated equal to $2.39 \times 10^{-2} \mathrm{~min}^{-1}$ at experimental condition. The semi-log plot of dye concentration versus time was linear, suggesting first order reaction. Efficiency of photodegradation process in the absence of $\mathrm{ZnO}$ photocatalyst and UV light was small. Increasing the UV irradiation time increased AO7 removal. Ethanol had inhibitory effect on this process. Maximum AO7 removal was seen at neutral $\mathrm{pH}$ area. In the $\mathrm{UV} / \mathrm{H}_{2} \mathrm{O}_{2}$ process, effect of some parameters such as presence of $\mathrm{H}_{2} \mathrm{O}_{2}$ and UV irradiation, amount of $\mathrm{H}_{2} \mathrm{O}_{2}$, effect of $\mathrm{pH}$ and addition of bicarbonate on the efficiency of dye removal were examined. Absence of each of UV irradiation or $\mathrm{H}_{2} \mathrm{O}_{2}$ decreased $\mathrm{AO} 7$ removal efficiency near to zero. Increasing $\mathrm{H}_{2} \mathrm{O}_{2}$ concentration increased dye removal to some extent but at higher $\mathrm{H}_{2} \mathrm{O}_{2}$ concentrations, dye removal efficiency did not increase. Increasing $\mathrm{pH}$ to value about 9 increased the $\mathrm{AO} 7$ removal efficiency and increasing bicarbonate anion concentration decreased it. Rate constant of $\mathrm{AO} 7$ removal by this process was calculated to be equal to $4.221 \times 10^{-1} \mathrm{~min}^{-1}$ at experimental condition. Also, the order of $\mathrm{UV} / \mathrm{H}_{2} \mathrm{O}_{2} / \mathrm{Fe}$ (III) $>\mathrm{UV} / \mathrm{H}_{2} \mathrm{O}_{2}>$ $\mathrm{UV} / \mathrm{Fe}$ (III) $>\mathrm{H}_{2} \mathrm{O}_{2} / \mathrm{Fe}$ (III), was seen for $\mathrm{AO} 7$ removal efficiency of these processes. Increasing $\mathrm{Fe}$ (III) and oxalate concentration increased dye removal efficiency.
\end{abstract}

KEYWORDS: C.I. Acid Orange 7, Advanced Oxidation Process, Photo Oxidation, Photofenton, $\mathrm{H}_{2} \mathrm{O}_{2}$, $\mathrm{ZnO}$

\section{INTRODUCTION}

Toxic dyes are very important in the viewpoint of environmental protection because they produce toxic aromatic amines and have other harmful environmental effects. They are widely used and have low degradation rate by aerobic treatment processes. Many of dye molecules are resistant to biological degradation (Baouer et al., 2001). Dying industries use approximately 10000 dyes and pigments, which are manufactured $7 \times 10^{5}$ ton per year, $50 \%$ of them are azo dyes (Zhu et al., 2000). Approximately $15 \%$ of synthetic toxic dyes are discharged into the wastewaters.

C.I. Acid Orange 7 (AO7) or Orange II (C.I. 15510) is a mono-azo acidic dye, which is soluble in water and has a tautomeric structure as figure 1 . AO7 is widely used in dying, weaving, tanning and paper industries (Mark et al., 1978) and therefore, it has wide environmental effects. 


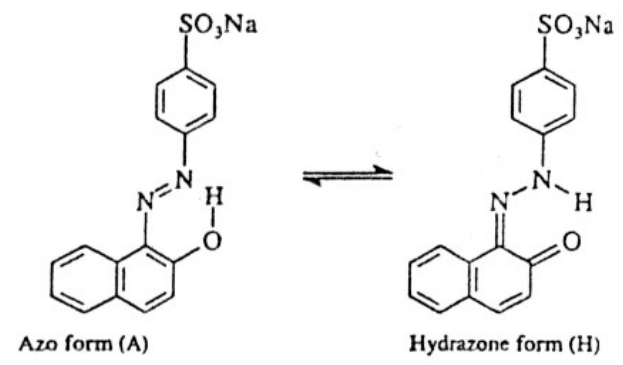

Figure 1. Tautomeric structures of $\mathrm{A} \mathrm{O} 7$

Advanced oxidation processes (AOPs) are the methods in which $\mathrm{OH}^{\circ}$ radicals are produced. $\mathrm{OH}^{\circ}$ is a powerful oxidizing agent and completely degrades the most of organic pollutants. It is possible to use some metallic oxides and sulfides as catalysts for these processes. These photocatalysts have a completed valence band and an empty conduction band. When one electron is excited from valence band to conduction band the photocatalytic property appears. Yeber et al. (1999) studied the photocatalytic treatment of paper pulp bleaching wastewater using $\mathrm{O}_{2} / \mathrm{ZnO} / \mathrm{UV}$ process and the results showed that the biodegradability of the wastewater increases. Lizama et al. (2002) studied the photocatalytic degradation of reactive blue 19 on $\mathrm{ZnO}$ and $\mathrm{TiO}_{2}$. They found that after 30 min UV exposure time, the removal is completed. They also found that in the case of RB19, the efficiency of $\mathrm{ZnO}$ is much more than $\mathrm{TiO}_{2}$, which is due to more production of $\mathrm{H}_{2} \mathrm{O}_{2}$ on the surface of $\mathrm{ZnO}$. Daneshvar et al. (2004) studied the photocatalytic removal of acid red 14 on $\mathrm{ZnO}$. They also studied the removal of rhodamin-B using UV/TiO 2 and UV/ZnO processes (Daneshvar et al., 2003; 2004).

Biological and also, photochemical removal of $\mathrm{AO} 7$ on $\mathrm{TiO}_{2}$ have been previously studied. But, because of wide consumption of $\mathrm{AO} 7$ in dying industries and regard to its environmental aspects, it is important to find a more efficient method to treat the wastewaters polluted with AO7. Advanced oxidation processes are good alternatives/complements for conventional methods and it will be beneficial to be studied. In this work we studied the effect of different parameters on $\mathrm{AO} 7$ removal by $\mathrm{UV} / \mathrm{ZnO}, \mathrm{UV} / \mathrm{H}_{2} \mathrm{O}_{2}, U V / \mathrm{H}_{2} \mathrm{O}_{2} / \mathrm{Fe}$ (III) (photofenton) and $\mathrm{UV} / \mathrm{H}_{2} \mathrm{O}_{2} / \mathrm{Fe}(\mathrm{III}) /$ oxalate processes.

\section{EXPERIMENTAL}

All experiments in this work were done in a batch photoreactor system consists of a wooden chamber with aluminum foil cover, UV-C lamp (30 W, Philips), magnetic stirrer and a $500 \mathrm{ml}$ beaker as reaction chamber. The system was cooled using air stream.

Proper volumes of $\mathrm{AO} 7$ stock solution were mixed with photocatalyst $(\mathrm{ZnO})$ or chemical reagents $\left(\mathrm{H}_{2} \mathrm{O}_{2}, \mathrm{Fe}\right.$ (III), oxalate) and were diluted to $100 \mathrm{ml}$. These suspensions were agitated in the absence of light for $30 \mathrm{~min}$ to reach the equilibrium. Absorbance of this solutions with proper $\mathrm{pH}(\mathrm{pH}$ meter: Metrohm 744) was determined at $\lambda=485 \mathrm{~nm} .50 \mathrm{ml}$ volumes of each of these solutions were transferred into the $500 \mathrm{ml}$ beakers as reactor chambers and were agitated and exposured by UV-C irradiation with the intensity of $0.55 \mathrm{klx}^{1}$ (illuminometer: Leybold Heraeus 53050). Then, the absorbance of taken samples was measured spectrophotometrically (spectrophotometer: double beam, Perkin Elmer $550 \mathrm{SE}$ ). Dye concentration of the samples was calculated using a calibration plot of absorbance vs. concentration. The conversion fraction of dye was calculated using the equation 1 :

$$
X=\frac{c_{0}-c}{c_{0}}=1-\frac{c}{c_{0}}
$$

in which $\mathrm{X}$ was conversion fraction, $\mathrm{c}$ was dye concentration $(\mathrm{ppm})$ at time $\mathrm{t}(\mathrm{min})$ and $\mathrm{c}_{0}$ was initial dye concentration (ppm).

The used $\mathrm{AO} 7$ had technical grade from Rang-Azar Co., $\mathrm{ZnO}$ as photocatalyst and $\mathrm{NaOH}$ and $\mathrm{H}_{2} \mathrm{SO}_{4}$ for $\mathrm{pH}$ adjustment were from Merck. Sodium bicarbonate, ethanol, oxalic acid, iron (III) chloride and sodium oxalate as reagents all were from Merck, too. $\mathrm{H}_{2} \mathrm{O}_{2} 30 \%$ as oxidizing agent was from Fluka.

\footnotetext{
${ }^{1}$ Kilolux: Unit of illuminance
} 


\section{RESULTS and DISCUSSION}

\subsection{UVIZnO process}

\subsubsection{Effect of UV irradiation time}

Figure 2 shows the effect of UV irradiation time on AO7 removal efficiency for $\mathrm{AO} 7$ concentration of $20 \mathrm{ppm}$ and $\mathrm{ZnO}$ concentration of $110 \mathrm{ppm}$. It can be seen that after $150 \mathrm{~min}$ irradiation time, conversion fraction of dye reached to 1 . This is because of increasing the excited $\mathrm{ZnO}$ particles with time and therefore, increasing the number of produced $\mathrm{OH}^{\circ}$ radicals and positive holes (Daneshvar et al., 2004).

\subsubsection{Determination of apparent rate constant of AO7 removal by UVIZnO process}

Using the data, which have been reported in section 3.1.1, it can be seen that plot of Ln c vs. irradiation time $(\mathrm{min})$ was linear and therefore, the reaction belonged to first order rate system (Figure 3 ) and $\mathrm{k}$ value was calculated equal to $2.39 \times 10^{-2} \mathrm{~min}^{-1}$.

\subsubsection{Effect of $Z n O$ and UV light}

Three solutions of AO7 with the concentration of $20 \mathrm{ppm}$ were prepared. One of them had $160 \mathrm{ppm} \mathrm{ZnO}$ and was irradiated with UV light for different times. Another one had $160 \mathrm{ppm}$ $\mathrm{ZnO}$ but was not exposured. The other one had not $\mathrm{ZnO}$ but exposured to UV light for different times. The results are shown in figure 4 and it can be seen that in the absence of UV light or $\mathrm{ZnO}$, the conversion fraction was near to zero. This shows that both of UV light and $\mathrm{ZnO}$ photocatalyst were necessary to efficiently remove the AO7 from solution. In the absence of these two factors, the production of $\mathrm{OH}^{\circ}$ radicals is negligible which causes low dye removal efficiency.

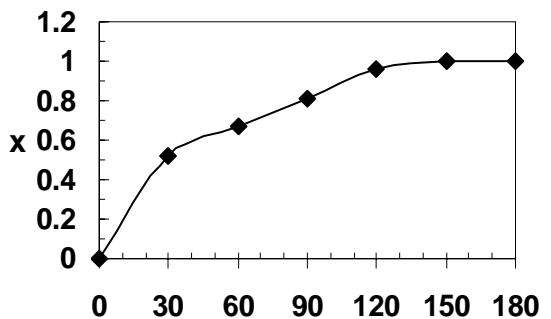

Figure 2. conversion Fraction vs. irradiation time in UV/ZnO process, [AO7]=20 ppm, $[\mathrm{ZnO}]=110 \mathrm{ppm}$

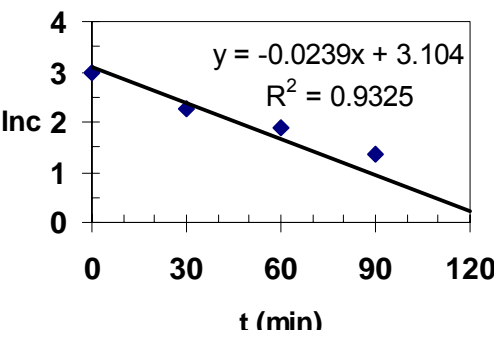

Figure 3. Ln [AO7] vs. irradiation time ( $\mathrm{min})$ plot to find first order rate constant of $\mathrm{UV} / \mathrm{ZnO}$ process, using the data of section 3.1.1

\subsubsection{Effect of $\mathrm{pH}$}

Figure 5 shows the effect of different $\mathrm{pH}$ values on $\mathrm{AO} 7$ removal at 60 min irradiation time and AO7 concentration of $20 \mathrm{ppm}$ and $\mathrm{ZnO}$ concentration of $160 \mathrm{ppm}$. It can be seen that removal efficiency was maximum at neutral $\mathrm{pH}$ area. At acidic $\mathrm{pH}$ values $\mathrm{ZnO}$ is dissolved as $\mathrm{Zn}^{2+}$ and has not any photocatalytic properties, and at basic $\mathrm{pH}$ values, $\mathrm{ZnO}$ particles have negative surface charge and repulse dye anion-molecules (Daneshvar et al., 2004). Negative charge on dye molecule originates from $\mathrm{SO}_{3}{ }^{-}$group substituted on aromatic ring.

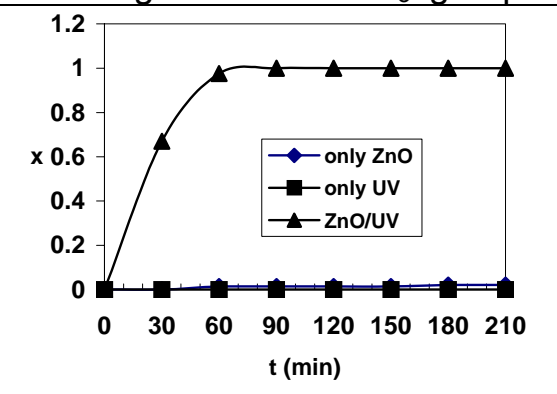

Figure 4. Effect of $\mathrm{ZnO}$ and UV irradiation in $\mathrm{UV} / \mathrm{ZnO}$ process, $[\mathrm{AO} 7]=20 \mathrm{PPM},[\mathrm{ZnO}]=0$ or $160 \mathrm{ppm}$

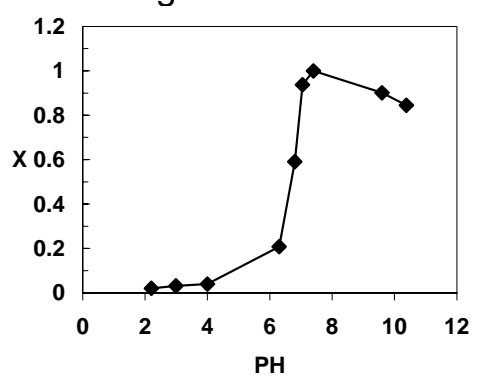

Figure 5. Effect of $\mathrm{pH}$ on $\mathrm{AO} 7$ removal in UVIZnO process, $[\mathrm{AO} 7]=20 \mathrm{ppm}$, $[\mathrm{ZnO}]=160 \mathrm{ppm}, \mathrm{t}=60 \mathrm{~min}$ 


\subsubsection{Effect of ethanol concentration on AO7 removal}

Figure 6 shows inhibitory effect of ethanol on AO7 removal after 60 min UV irradiation time at AO7 concentration of $20 \mathrm{ppm}$ and $\mathrm{ZnO}$ concentration of $160 \mathrm{ppm}$. It can be seen that increasing ethanol concentration, decreased the efficiency of AO7 removal because ethanol quenches $\mathrm{OH}^{\circ}$ radicals.

\subsubsection{Effect of $\mathrm{ZnO}$ concentration on AO7 removal}

Figure 7 shows the effect of $\mathrm{ZnO}$ concentration on $\mathrm{AO} 7$ removal during $180 \mathrm{~min}$ UV irradiation time at $\mathrm{AO} 7$ concentration of $20 \mathrm{ppm}$ and $\mathrm{ZnO}$ concentration ranging from $100 \mathrm{ppm}$ to 200 $\mathrm{ppm}$. It can be seen that $160 \mathrm{ppm}$ concentration of $\mathrm{ZnO}$ had the maximum dye removal efficiency about $100 \%$ after 90 min irradiation time. This result could be explained by increasing photocatalitically active sites of $\mathrm{ZnO}$ with increasing its concentration up to 160 $\mathrm{ppm}$. Further increasing $\mathrm{ZnO}$ concentration increases solution turbidity and decreases UV light penetration into the solution and therefore, the removal efficiency decreases (Kartal et al., 2001).

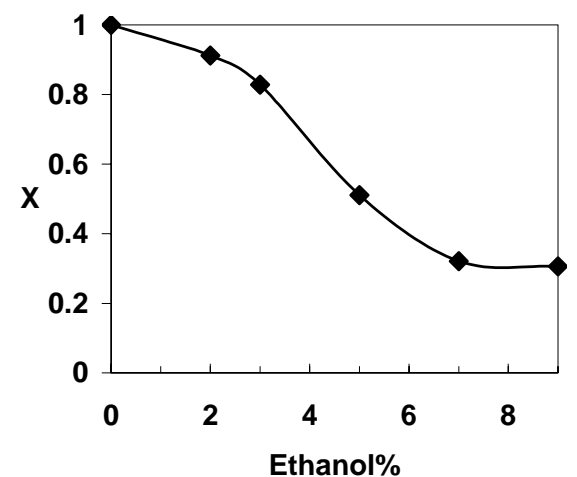

Figure 6. Effect of ethanol concentration on conversion fraction of $\mathrm{AO} 7$ in UV/ZnO process, $[\mathrm{AO}]=20 \mathrm{ppm},[\mathrm{ZnO}]=160 \mathrm{ppm}$, $\mathrm{t}=60 \mathrm{~min}$

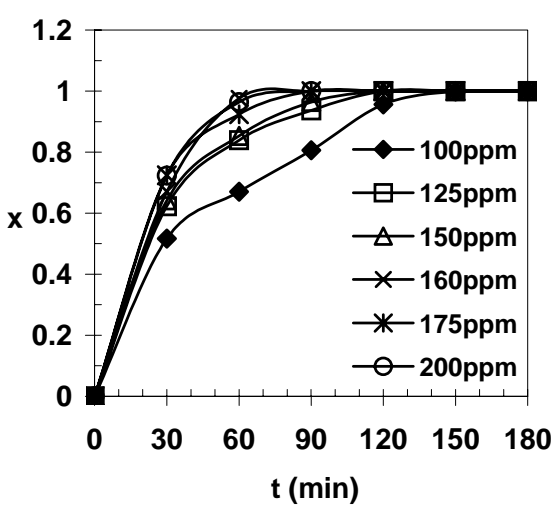

Figure 7. Effect of $\mathrm{ZnO}$ concentration on $\mathrm{AO} 7$ removal in UV/ZnO process, $[\mathrm{AO} 7]=20 \mathrm{ppm}$

\subsubsection{Effect of $A O 7$ concentration on its removal}

Figure 8 shows the effect of $\mathrm{AO} 7$ concentration on its removal during 150 min UV irradiation time at $\mathrm{AO} 7$ concentration ranging from $20 \mathrm{ppm}$ to $60 \mathrm{ppm}$ and $\mathrm{ZnO}$ concentration of 160 ppm. It can be seen that increasing dye concentration from $20 \mathrm{ppm}$ to $60 \mathrm{ppm}$ decreased removal efficiency of dye in the solution. The AO7 solution with a high initial concentration substantially absorbs more UV light than that with a low initial concentration, as a result, the number of photons becomes less due to the decrease intensity of UV light, leading a decrease in the formation of hydroxyl radicals and this, decreases AO7 removal efficiency (Daneshvar et al., 2004).

\subsubsection{Effect of $\mathrm{H}_{2} \mathrm{O}_{2}$ concentration on $\mathrm{AO} 7$ removal}

Figure 9 shows effect of $\mathrm{H}_{2} \mathrm{O}_{2}$ concentration on $\mathrm{AO} 7$ removal during 20 min UV irradiation time at $\mathrm{AO} 7$ concentration of $20 \mathrm{ppm}$ and $\mathrm{ZnO}$ concentration of $160 \mathrm{ppm}$. It can be seen that increasing $\mathrm{H}_{2} \mathrm{O}_{2}$ concentration up to $10 \mathrm{mmol} \mathrm{I}^{-1}$, increased $\mathrm{AO} 7$ removal efficiency to more than $90 \%$, which is due to capture of photochemically released electrons on the photocatalyst surface. This increases $\mathrm{OH}^{\circ}$ concentration and so, AO7 removal efficiency increases (Daneshvar et al., 2004).

$$
\mathrm{H}_{2} \mathrm{O}_{2}+\mathrm{ZnO}(\overline{\mathrm{e}}) \rightarrow 2 \mathrm{OH}^{\mathrm{O}}+\mathrm{ZnO}
$$

At higher concentrations, $\mathrm{H}_{2} \mathrm{O}_{2}$ quenches $\mathrm{OH}^{\circ}$ radicals and so, dye removal efficiency decreases (Daneshvar et al., 2004). 


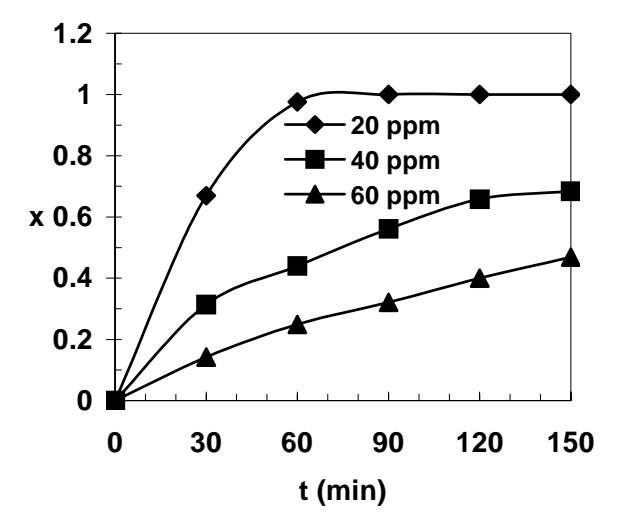

Figure 8. Effect of $\mathrm{AO} 7$ concentration on its removal in UV/ZnO process, $[\mathrm{ZnO}]=160 \mathrm{ppm}$

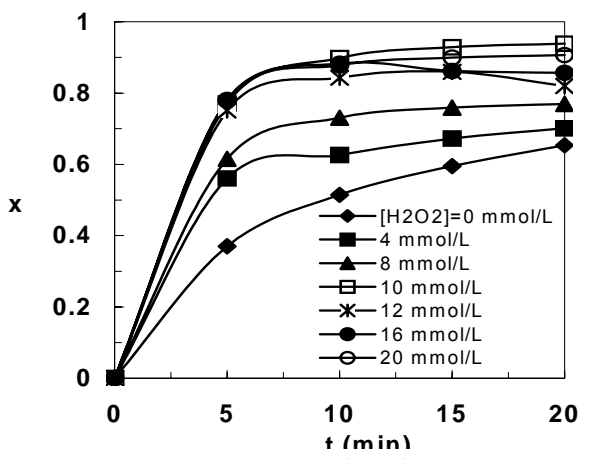

Figure 9. Effect of $\mathrm{H}_{2} \mathrm{O}_{2}$ concentration on $\mathrm{AO} 7$ removal in UV/ZnO process, [AO7] $=20$ $\mathrm{ppm},[\mathrm{ZnO}]=160 \mathrm{ppm}$

\section{2. $\mathrm{UV} / \mathrm{H}_{2} \mathrm{O}_{2}$ process}

3.2.1. Effect of UV light and $\mathrm{H}_{2} \mathrm{O}_{2}$ on $\mathrm{AO} 7$ removal

Figure10 compares the $\mathrm{AO} 7$ removal efficiency between three solutions with $20 \mathrm{ppm} \mathrm{AO7,}$ one in presence of UV light and $\mathrm{H}_{2} \mathrm{O}_{2}\left(0.5 \mathrm{mmol} \mathrm{I}^{-1}\right)$, another one in absence of $\mathrm{H}_{2} \mathrm{O}_{2}$ and the other one in the absence of UV irradiation. It is obvious that absence of each of UV irradiation or $\mathrm{H}_{2} \mathrm{O}_{2}$, decreased production of $\mathrm{OH}^{\circ}$ radicals and therefore $\mathrm{AO} 7$ removal efficiency was near to zero.

\subsubsection{Effect of different concentrations of $\mathrm{H}_{2} \mathrm{O}_{2}$ on $\mathrm{AO} 7$ removal}

Figure 11 shows the effect of different concentrations of $\mathrm{H}_{2} \mathrm{O}_{2}$ on $\mathrm{AO} 7$ removal after $12.5 \mathrm{~min}$ UV irradiation time at $A O 7$ concentration of $20 \mathrm{ppm}$. It can be seen that increasing $\mathrm{H}_{2} \mathrm{O}_{2}$ concentration, increased $\mathrm{AO} 7$ removal efficiency but at high $\mathrm{H}_{2} \mathrm{O}_{2}$ concentrations, the produced $\mathrm{OH}^{\circ}$ radicals react with each other and therefore, AO7 removal efficiency did not more increase.

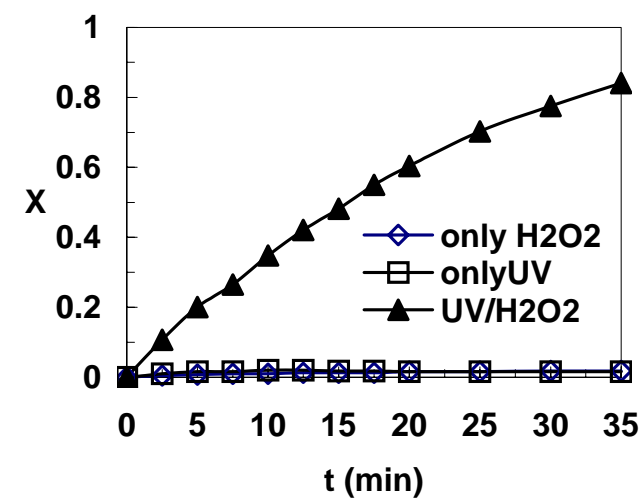

Figure 10. Effect of presence of $\mathrm{H}_{2} \mathrm{O}_{2}$ and UV irradiation on $\mathrm{AO} 7$ removal in $\mathrm{UV} / \mathrm{H}_{2} \mathrm{O}_{2}$ process, $[\mathrm{AO} 7]=20 \mathrm{ppm}$

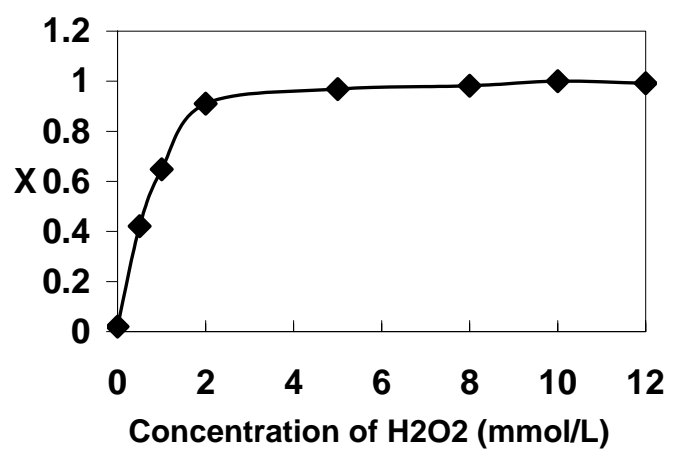

Figure 11. Effect of concentration of $\mathrm{H}_{2} \mathrm{O}_{2}$ on $\mathrm{AO} 7$ removal in $\mathrm{UV} / \mathrm{H}_{2} \mathrm{O}_{2}$ process, $[\mathrm{AO}] \mathrm{l}=20 \mathrm{ppm}, \mathrm{t}=12.5 \mathrm{~min}$

\subsubsection{Effect of bicarbonate anion on AO7 removal efficiency}

As it is shown in figure 12, increasing bicarbonate concentration up to $2 \mathrm{mmol} \mathrm{I}^{-1}$ in a solution with $\mathrm{AO} 7$ concentration of $20 \mathrm{ppm}$ and $10 \mathrm{mmol} \mathrm{I^{-1 }}$ of $\mathrm{H}_{2} \mathrm{O}_{2}$, decreased $\mathrm{AO} 7$ removal efficiency because bicarbonate reacts with $\mathrm{OH}^{\circ}$ as follow (Pirkanniemi and Sillanpaa, 2002):

$\mathrm{OH}^{\circ}+\mathrm{HCO}_{3}^{-} \rightarrow \mathrm{H}_{2} \mathrm{O}+\mathrm{CO}_{3}^{\circ-}$

$\mathrm{OH}^{\circ}+\mathrm{CO}_{3}^{2-} \rightarrow \mathrm{OH}^{-}+\mathrm{CO}_{3}^{\circ-}$ 


\subsubsection{Effect of $\mathrm{pH}$ on $\mathrm{AO} 7$ removal}

Figure 13 shows the conversion fraction of $\mathrm{AO} 7$ in a solution with its initial concentration of 20 ppm and concentration of $\mathrm{H}_{2} \mathrm{O}_{2}$ equal to $10 \mathrm{mmol} \mathrm{I}^{-1}$, at basic $\mathrm{pH}$ values was more than acidic solutions. Since, at higher $\mathrm{pH}$ values according to equations 5 and 6 , some excess $\mathrm{OH}^{\circ}$ radicals are produced as followings:

$$
\begin{aligned}
& \mathrm{H}_{2} \mathrm{O}_{2} \leftrightarrow \mathrm{H}^{+}+\mathrm{HO}_{2}^{-} \quad \mathrm{K}_{\mathrm{a}}=2.7 \times 10^{-12} \\
& \mathrm{H}_{2} \mathrm{O}_{2}+\mathrm{HO}_{2}^{-} \rightarrow \mathrm{H}_{2} \mathrm{O}+\mathrm{O}_{2}^{-}+\dot{\mathrm{OH}}
\end{aligned}
$$

\subsubsection{Further studies}

Study of other parameters such as UV irradiation time and initial dye concentration, found that there were trends similar to ones about UV/ZnO process. Also, determination of apparent rate constant of $\mathrm{AO} 7$ removal by $\mathrm{UV} / \mathrm{H}_{2} \mathrm{O}_{2}$ process in an experiment with $\mathrm{AO} 7$ concentration of 20 ppm and $\mathrm{H}_{2} \mathrm{O}_{2}$ concentration of $10 \mathrm{mmol} \mathrm{I^{-1 }}$ with a method similar to one about UV/ZnO process, gave $\mathrm{K}=4.221 \times 10^{-1} \mathrm{~min}^{-1}$.

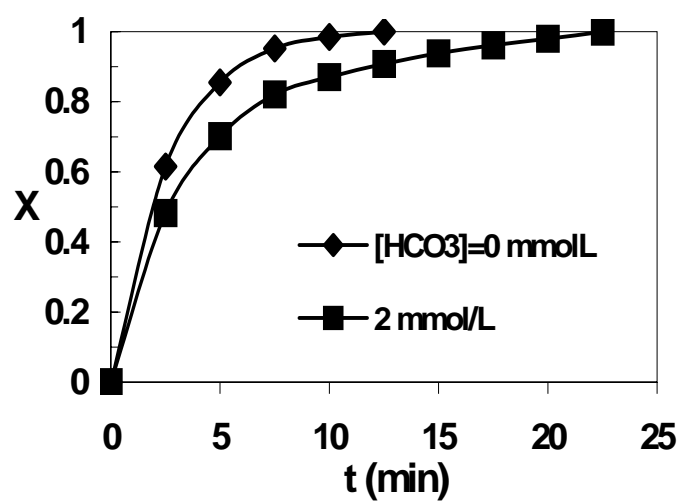

Figure 12. Effect of bicarbonate on $\mathrm{AO} 7$ removal in $\mathrm{UV} / \mathrm{H}_{2} \mathrm{O}_{2}$ process, [AO7] $=20 \mathrm{ppm}$, $\left[\mathrm{H}_{2} \mathrm{O}_{2}\right]=10 \mathrm{mmol} \mathrm{I}^{-1}$

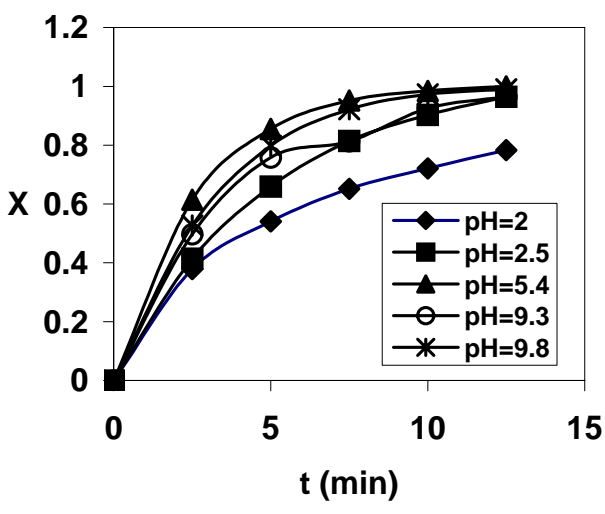

Figure 13. Effect of $\mathrm{pH}$ on $\mathrm{AO} 7$ removal in $\mathrm{UV} / \mathrm{H}_{2} \mathrm{O}_{2}$ process, [AO7] $=20 \mathrm{ppm}$, $\left[\mathrm{H}_{2} \mathrm{O}_{2}\right]=10 \mathrm{mmol} \mathrm{I}^{-1}$

\subsection{UV/ $\mathrm{H}_{2} \mathrm{O}_{2} / \mathrm{Fe}$ (III) and UVI $\mathrm{H}_{2} \mathrm{O}_{2} / \mathrm{Fe}$ (III)/ oxalate processes}

3.3.1. Effect of UV irradiation, $\mathrm{Fe}$ (III) and $\mathrm{H}_{2} \mathrm{O}_{2}$ on AO7 removal

Figure 14 shows the effect of UV irradiation, $\mathrm{Fe}$ (III) and $\mathrm{H}_{2} \mathrm{O}_{2}$ on conversion fraction of $\mathrm{AO} 7$ in a 20-ppm dye solution. The concentrations of $\mathrm{H}_{2} \mathrm{O}_{2}$ and Fe (III) were 5 and $0.1 \mathrm{mmol} \mathrm{I}^{-1}$, respectively when they were present in the solution. It is obvious that the photofenton (UV/ $\left.\mathrm{H}_{2} \mathrm{O}_{2} / \mathrm{Fe}(\mathrm{III})\right)$ process had the highest $\mathrm{AO} 7$ removal efficiency, and $\mathrm{UV} / \mathrm{H}_{2} \mathrm{O}_{2}$, UV/Fe (III) and $\mathrm{H}_{2} \mathrm{O}_{2} / \mathrm{Fe}$ (III) processes had lower efficiencies, respectively. This order can be related to the amount of $\mathrm{OH}^{\circ}$ radicals produced in each process.

\subsubsection{Effect of amount of Fe (III) on AO7 removal}

Figure 15 shows the effect of $\mathrm{Fe}$ (III) on $\mathrm{AO} 7$ removal in a solution with dye concentration of $20 \mathrm{ppm}$ and $\mathrm{H}_{2} \mathrm{O}_{2}$ concentration of $5 \mathrm{mmol} \mathrm{I}^{-1}$ and UV irradiation time of $10 \mathrm{~min}$. It shows that increasing the concentration of $\mathrm{Fe}$ (III), increased $\mathrm{AO} 7$ removal efficiency, up to $100 \%$ at $\mathrm{Fe}$ (III) concentration of $0.08 \mathrm{mmol}^{-1}$. This is because of increasing $\mathrm{OH}^{\circ}$ radicals in the presence of Fe (III) but at high Fe (III) concentrations, the increase of a brown turbidity in the solution during the photooxidation process, which hinders the absorption of the UV light required for the process, and consumption of $\mathrm{OH}^{\circ}$ by high amounts of Fe (II) produced, decreases the concentration of $\mathrm{OH}^{\circ}$ radicals which decreases dye removal efficiency (Daneshvar et al., 2006). 


\subsubsection{Effect of oxalate anion on AO7 removal}

Figure 16 shows the effect of different oxalate concentrations on $\mathrm{AO} 7$ removal in solutions with dye concentration of $20 \mathrm{ppm}, \mathrm{H}_{2} \mathrm{O}_{2}$ concentration of $5 \mathrm{mmol} \mathrm{I}^{-1}$ and $\mathrm{Fe}$ (III) concentration of $0.08 \mathrm{mmol} \mathrm{I}^{-1}$. It can be seen that increasing the oxalate concentration, increased AO7 removal efficiency, which is due to increasing the $\mathrm{OH}^{\circ}$ concentration (Safarzadeh et al., 1997).

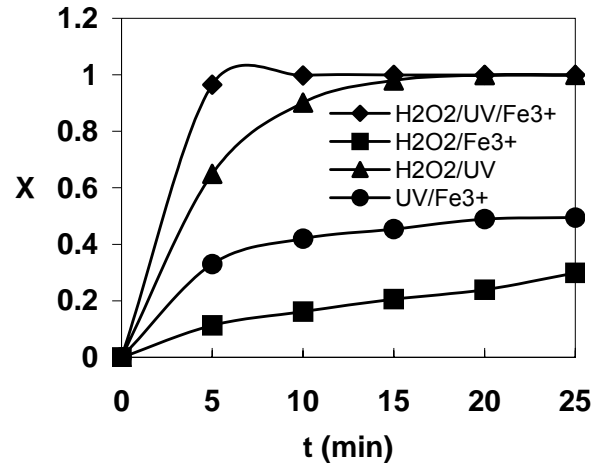

Figure 14. Effect of $\mathrm{H}_{2} \mathrm{O}_{2}, \mathrm{Fe}$ (III) and UV irradiation on $\mathrm{AO} 7$ removal, $[\mathrm{AO} 7]=20 \mathrm{ppm}$

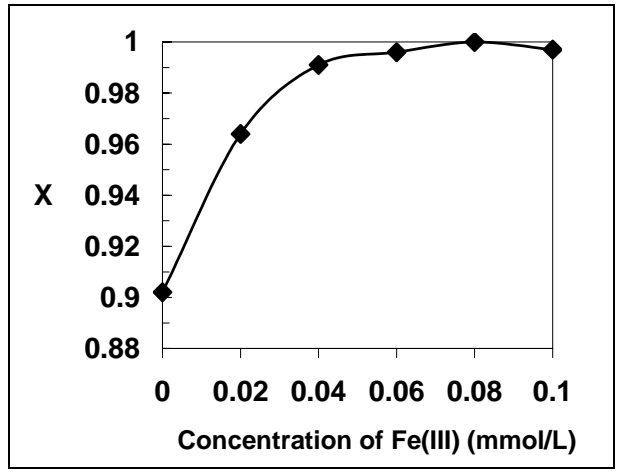

Figure 15. Effect of $\mathrm{Fe}$ (III) on AO7 removal in $\mathrm{UV} / \mathrm{H}_{2} \mathrm{O}_{2} / \mathrm{Fe}$ (III) process, [AO7] $=20 \mathrm{ppm}$, $\left[\mathrm{H}_{2} \mathrm{O}_{2}\right]=5 \mathrm{mmol} \mathrm{I}^{-1}, \mathrm{t}=10 \mathrm{~min}$

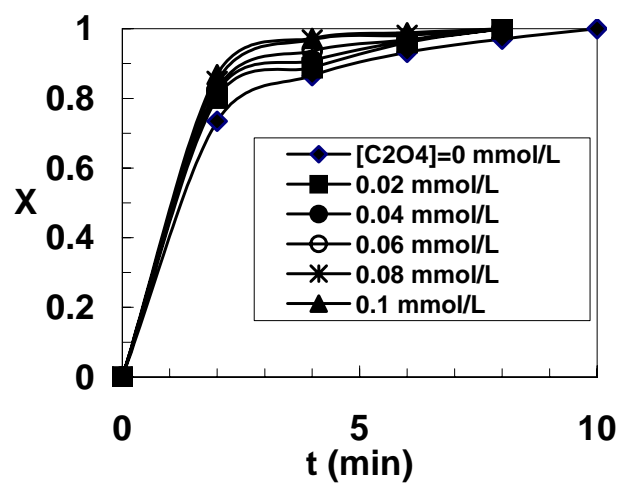

Figure 16. Effect of oxalate on $\mathrm{AO} 7$ removal in $\mathrm{UV} / \mathrm{H}_{2} \mathrm{O}_{2} / \mathrm{Fe}$ (III) process, [AO7] $=20 \mathrm{ppm}$, $\left[\mathrm{H}_{2} \mathrm{O}_{2}\right]=5 \mathrm{mmol} \mathrm{I}^{-1}$, [ Fe (III)] $=0.08 \mathrm{mmol} \mathrm{I}^{-1}$

\section{CONCLUSIONS}

Advanced oxidation processes of UV/ZnO, UV/ $\mathrm{H}_{2} \mathrm{O}_{2}, \mathrm{UV} / \mathrm{H}_{2} \mathrm{O}_{2} / \mathrm{Fe}$ (III) and $\mathrm{UV} / \mathrm{H}_{2} \mathrm{O}_{2} / \mathrm{Fe}$ (III)/oxalate systems were efficient methods to remove $\mathrm{AO} 7$ from aqueous solutions. From the data which were obtained in the experimental conditions it is obvious that:

- In UVIZnO process, increasing the UV irradiation time increased the AO7 removal. This process belonged to first order rate system. In this system, absence of each of $\mathrm{ZnO}$ or UV irradiation decreased AO7 removal efficiency near to zero. Increasing $\mathrm{ZnO}$ concentration first increased dye removal efficiency but after some extent, removal efficiency decreased. Also $\mathrm{H}_{2} \mathrm{O}_{2}$ had similar effect to $\mathrm{ZnO}$ but with different mechanism. Maximum AO7 removal efficiency was seen in neutral $\mathrm{pH}$ area, and increasing ethanol concentration decreased removal of dye.

- In UV/ $\mathrm{H}_{2} \mathrm{O}_{2}$ process the absence of each of UV irradiation or $\mathrm{H}_{2} \mathrm{O}_{2}$ decreased $\mathrm{AO} 7$ removal efficiency near to zero. Increasing $\mathrm{H}_{2} \mathrm{O}_{2}$ concentration increased dye removal to some extent but at higher $\mathrm{H}_{2} \mathrm{O}_{2}$ concentrations dye removal efficiency did not more increase. Increasing $\mathrm{pH}$ to values about 9 , increased $\mathrm{AO} 7$ removal efficiency. This process belonged to first order rate system, too. Increasing bicarbonate anion concentration decreased AO7 removal efficiency.

- This order: UV/ $\mathrm{H}_{2} \mathrm{O}_{2} / \mathrm{Fe}$ (III) $>$ UV/ $\mathrm{H}_{2} \mathrm{O}_{2}>\mathrm{UV} / \mathrm{Fe}$ (III) $>\mathrm{H}_{2} \mathrm{O}_{2} / \mathrm{Fe}$ (III), was seen for AO7 removal efficiency and increasing $\mathrm{Fe}$ (III) and oxalate concentration increased dye removal efficiency. 


\section{ACKNOWLEDGEMENT}

The authors of this paper are thankful for the University of Tabriz for its financial and other supports of this work.

\section{REFERENCES}

Bauer Ch., Jacques P.and Kalt A. (2001) Photooxidation of an azo dye induced by visible light incident on the surface of $\mathrm{TiO}_{2}$, J. Photochem. Photobiol. A: Chemistry, 140, 87-92.

Daneshvar N., Salari D. and Khataee A.R. (2004) Photocatalytic degradation of azo dye acid red 14 in water on $\mathrm{ZnO}$ as an alternative catalyst to $\mathrm{TiO}_{2}$, J. Photochem. Photobiol. A: Chem, 162, 317-322.

Daneshvar N. and Khataee A. R. (2006) Removal of Azo Dye C.I. Acid Red 14 from Contaminated Water using Fenton, UV/H2O2, UV/H2O2/Fe(II), UV/H2O2/Fe(III) and UV/H2O2/Fe(III)/Oxalate Processes: A Comparative Study, Journal of Environmental Science and Health Part A, 41, 315-328.

Daneshvar N., Rasoulifard M.H., Jamshidi S., Ansari P. and Khataee, A.R. (2003) Photocatalytic oxidation of Rhodamine $\mathrm{B}$ in the polluted waters by $\mathrm{UV} / \mathrm{TiO}_{2}$ and $\mathrm{UV} / \mathrm{ZnO}$ and comparison of reaction rates (Persian), Proc. 8th National Iranian Chemical Engineering Congress, University of Mashhad, Iran 2003.

Daneshvar N., Salari D., Niaei A.G. and Rasouli Fard M.H. (2004) Immobilization of $\mathrm{TiO}_{2}$ on glass beds and photocatalytic degradation of Rhodamin B, Malachite green and Red 23 by Supported $\mathrm{TiO}_{2}$ Under UV irradiation, Proc. 14th Iranian Chemistry \& Chemical Engineering Congress, Tehran, Iran 2004.

Kartal O.E., Erol M., Oguz H. (2001) Photocatalytic Destruction of Phenol by $\mathrm{TiO}_{2}$ Powders, Chem. Eng. Technol., 24, 645-649.

Lizama C., Freer J., Baeza J. and Mansilla Hector D. (2002) Optimized photodegradation of Reactive Blue 19 on $\mathrm{TiO}_{2}$ and $\mathrm{ZnO}$ suspensions, Catalysis Today, 76, 235-246.

Mark H.F., Othmer O.F., Overbrger C.G. and Seaborg G.T. (1978) Encyclopedia of Chemical Technology, Vol. 3, John Wiley and Sons, USA, 387-406.

Pirkanniemi K. and Sillanpaa M. (2002) Heterogeneous water phase catalysis as an environmental application: a review, Chemosphere, 48, 1047-1060.

Safarzadeh A.A., Bolton J.R. and Cater S.R. (1997) Ferrioxalate-mediated photodegradation of organic pollutants in contaminated water, Wat. Res., 31, 787-798.

Yeber M.C., Rodriguez J., Freer J., Baeza J., Duran N. and Mansilla H.D. (1999) Advanced oxidation of a pulp mill bleaching wastewater, Chemosphere, 39, 1679-1688.

Zhu C., Wang L., Kong L., Yang X., Wang L., Zheng S., Chen F., Maizhi F. and Zong H. (2000) Photocatalytic degradation of $\mathrm{AZO}$ dyes by supported $\mathrm{TiO}_{2}+\mathrm{UV}$ in aqueous solution, Chemosphere, 41, 303-309. 